\title{
URINARY TRACT INFECTION DUE TO EXTENDED- SPECTRUM BETA-LACTAMASE PRODUCING ORGANISMS IS A RISK FACTOR FOR BACTERAEMIA AMONG PATIENTS WITH TYPE 2 DIABETES MELLITUS
}

\author{
MUHAMMAD ABDUR RAHIM ${ }^{1}$, SHAHANA ZAMAN ${ }^{2}$, ISHRAT JAHAN ${ }^{1}$, SAMIRA HUMAIRA HABIB ${ }^{3}$, TABASSUM \\ SAMAD $^{1}$, TUFAYEL AHMED CHOWDHURY ${ }^{1}$, SHUDHANSHU KUMAR SAHA ${ }^{1}$, ABDUL LATIF ${ }^{1}$, MOHAMMAD \\ MEHFUZ-E-KHODA ${ }^{1}$, MD. MOSTARSHID BILLAH ${ }^{1}$, MEHRUBA ALAM ANANNA ${ }^{1}$, SARWAR IQBAL $^{1}$
}

\begin{abstract}
Introduction: Urinary tract infection (UTI) is common among patients with diabetes mellitus and the aetiological agents are often extended-spectrum beta-lactamase (ESBL) producing bacteria. Diabetic patients with UTI are sometimes complicated by bacteraemia. This study was designed to evaluate whether UTI due to ESBL-positive organisms is a risk factor for bacteraemia among patients with type 2 diabetes mellitus.

Methods: This was a cross-sectional analytical study, done in BIRDEM General Hospital, Dhaka, Bangladesh from January to April 2016. Adult (e"18 years) type 2 diabetic subjects of either sex with culture proven UTI were included in this study. All study participants were subjected to undergo blood cultures as well. ESBL-positivity of the infective organisms for UTI was evaluated as possible risk factor for bacteraemia.

Results: Total patients were 145 including 119 (82\%) females. Eshcerichia coli (112, 77.2\%) was the most common aetiological agents followed by Klebsiella pneumoniae (28, 19.3\%). In 54 (37.2\%) patients UTI was due to ESBL-positive organisms. Ten (6.9\%) patients were complicated by bacteraemia [7 (7/) 54, 13\%) among patients with UTI due to ESBL-positive organisms and 3 (3/91, 3.3\%) among patients with UTI due to non-ESBL organisms]. UTI due to ESBL-positive organisms appeared as a significant risk factor for bacteraemia (OR 4.37, 95\% CI 1.08-17.38, $p$ 0.03).

Conclusion: Nearly two-fifths of UTI cases were due to ESBL-positive organisms in this study. ESBLpositivity of the causative organisms was a significant risk factor for bacteraemia among type 2 diabetic subjects.
\end{abstract}

Key words: Bacteraemia, extended-spectrum beta-lactamase, pyelonephritis, risk factor, type 2 diabetes mellitus, urinary tract infection.

Received: 05 August 2019

Accepted: 18 December 2019

DOI: https://doi.org/10.3329/bjmed.v31i1.44747

\section{Introduction}

Urinary tract infection (UTI) is the most common bacterial infection in adults and elderly population and patients with diabetes mellitus are at increased risk for UTI. ${ }^{1-3}$ UTI, specially pyelonephritis may be complicated by bacteraemia and sepsis.4,5 Antimicrobials remain the cornerstone for treatment of UTI and increasing antimicrobial resistance, specially extended-spectrum beta-lactamase (ESBL) producing organisms is an ever increasing problem. ${ }^{6-}$ 9 ESBL-positive organisms are inherently resistant to penicillin and cephalosporin; thus UTI caused by ESBLpositive organism require injectable agents like carbapenems and aminoglycosides or nitrofurantoin, pivmecillinam and fluoroquinolones; many organisms causing UTI are also resistant to these oral agents. ${ }^{2,8}$

1. Nephrology, BIRDEM General Hospital, Dhaka, Bangladesh.

2. Cardiology, NICVD, Dhaka, Bangladesh.

3. Health Economics Unit, BADAS, Dhaka, Bangladesh.

Address of correspondence: Muhammad Abdur Rahim, Associate Professor, Nephrology, BIRDEM General Hospital, Dhaka, Bangladesh. Email: muradrahim23@yahoo.com 
Moreover, UTI complicated by bacteraemia indicates complicated infection and merits intravenous antimicrobials in hospital settings; thus increasing treatment cost by many folds. So, this study was designed to evaluate whether UTI due to ESBL-positive organisms is a risk factor for bacteraemia among patients with type 2 diabetes mellitus.

\section{Methods}

This cross-sectional analytical study was done in the Department of Nephrology, Bangladesh Institute of Research and Rehabilitation in Diabetes, Endocrine and Metabolic Disorders (BIRDEM) General Hospital, Dhaka, Bangladesh from January to April 2016. Hospitalized adult (e"18 years) type 2 diabetic subjects of either sex, who got admitted with features of pyelonephritis, were primarily enrolled for the study purpose. A clean catch technique was applied for collection of urine in a sterile container and sent to the microbiology laboratory of the institute within half an hour for culture and a blood sample of the patient was also sent for culture before starting any antibiotic. Urine and blood cultures and antibiotic sensitivity tests were performed following standard microbiological procedures. Other investigations were done as per hospital protocol and as indicated. Patients with culture proven UTI were finally included in this study. ESBL-positivity of the infective organisms was tested by double disc diffusion method described elsewhere. ${ }^{10}$ Pregnant patients, patients with kidney and ureteric stones, enlarged prostate, indwelling urinary catheter and recurrent UTI were excluded from the study. ESBL-positivity of the infective organisms was evaluated as possible risk factor for bacteramia. Data were analyzed by statistical package for social scientists (SPSS) version 16.0 and the results

\section{Results}

Total patients were 145 including 119 (82\%) females. Mean age of the study participants was 59.2 years. Base-line characteristics are shown in Table I.

Table-I

Base-line characteristics of the study participants $(\mathrm{N}=145)$

\begin{tabular}{lc}
\hline Characteristics & Parameters \\
\hline Mean (range) age & $59.2(21-72)$ years \\
Male: Female & $1: 4.6$ \\
Mean (range) duration of & $6.3(1-13)$ years \\
diabetes & \\
Random blood glucose at & $13.1(7.2-21.3) \mathrm{mmol} / \mathrm{L}$ \\
admission & \\
Mean (range) HbA1c & $9.7(8.1-11.5) \%$ \\
Hypertension & $68(46.9 \%)$ \\
Chronic kidney disease & $41(28.3 \%)$ \\
\hline
\end{tabular}

Eshcerichia coli $(112,77.2 \%)$ was the most common aetiological agents followed by Klebsiella pneumoniae (28, 19.3\%). Other organisms are presented in Table II. In 54 (37.2\%) patients UTI was due to ESBL-positive organisms and in 91 (62.8\%) patients UTI was due to non-ESBL organisms. Ten (6.9\%) patients were complicated by bacteremia; $7(7 / 54,13 \%)$ among patients with UTI due to ESBL-positive organisms and 3 (3/91, 3.3\%) among patients with UTI due to nonESBL organisms. UTI due to ESBL-positive organisms appeared as a significant risk factor for bacteramia ( $p$ 0.03) (Table III).

Table II

Patterns of infective organisms for UTI $(\mathrm{N}=145)$

\begin{tabular}{lccc}
\hline Organism & ESBL-positive & Non-ESBL & Total \\
\hline E. coli & $38(33.9)$ & $74(66.1)$ & 112 \\
K. pneumoneae & $11(39.3)$ & $17(60.7)$ & 28 \\
Enterobacter & $4(100)$ & $0(0)$ & 4 \\
Citrobacter & $1(100)$ & $0(0)$ & 1 \\
\hline
\end{tabular}

Table III

ESBL-positivity as a risk factor for sepsis among patients with UTI $(N=145)$

\begin{tabular}{lccc}
\hline ESBL & $\begin{array}{c}\text { Sepsis } \\
\text { positivity }\end{array}$ & $\begin{array}{c}\text { No sepsis } \\
(13)\end{array}$ & $\begin{array}{c}\text { OR, 95\% } \\
\text { CI, p value }\end{array}$ \\
\hline Yes (54) & 7 & 47 & $4.37,1.08-17.38,0.03$ \\
No (91) & 3 & 88 & \\
\hline
\end{tabular}

\section{Discussion}

Bacteramia is not uncommon in UTI, both in community and hospital settings and in all age groupsadults, elderly and neonates; but the burden varied widely in different studies. ${ }^{11-13}$ Generally, outcome of UTI complicated by bacteramia is worse than those without. ${ }^{14}$ In the present study, we found nearly $7 \%$ of our type 2 diabetic subjects diagnosed with UTI had concomitant bacteramia. In different studies percentage of patients of UTI complicated by bacteramia was much higher ${ }^{11,12}$; elderly patients are likely to have urinary obstruction that might explain such high rates in western studies. ${ }^{11}$

In the present study, almost two-fifths of the study participants had UTI due to ESBL-positive organisms which is lower than a previous report from Bangladesh. ${ }^{8}$ Patients with diabetes mellitus and specially those with poor glycaemic control are at increased risk for infection with ESBL-positive organisms. ${ }^{2,15-17}$ The percentage of ESBL-positive 
organisms was higher in our study compared to some other international reports. ${ }^{16,18}$ Inadvertent and nonjudicious use of antimicrobials may be one of the most important contributory factors for such findings in the present study.

Community acquired UTI cases are generally treated at outpatients with oral fluroquinolones, cephalosporins and nitrofurantoin. ESBL-positive organisms are resistant to penicillins and cephalosporins. ${ }^{2}$ One-third of our patients had chronic kidney disease, but nobody was on renal replacement therapy in any form. Patients with chronic kidney disease are not suitable for prescriptions with nitrofurantoin or aminoglycosides. So, carbapenems remain the option, thus increasing treatment cost by many folds. ${ }^{6}$

Bacteramia itself implies severe disease. Published reports varied regarding outcome of UTI cases complicated by sepsis; some authors found worse outcome while others did not. ${ }^{4,19-21}$ Morbidity and mortality evaluation was beyond the scope of the present study but we feel outcome evaluation in UTI complicated by bacteramia remains area for further exploration in our setting.

Published literatures indicated urinary obstruction like enlarged prostate, indwelling catheters, stone disease and lithotripsy as risk factors for bacteramia and sepsis in UTI. 5,12,22-24 We excluded all these confounders in our study during selection of study participants. We assume duration of diabetes and status of glycaemic control could be further confounders in our study, which could be adjusted during analysis. Moreover, small sample size, short term study in a single centerall these remain as limitations of present study.

In conclusion, almost two-fifths of UTI cases were due to ESBL-positive organisms in this study and ESBLpositivity of the causative organisms for UTI was a significant risk factor for bacteramia among type 2 diabetic subjects.

Conflict of interest: Nothing to declare.

\section{References}

1. Nicolle LE. Urinary Tract Infections in the Older Adult. Clin Geriatr Med 2016 Aug;32(3):523-538.https:// doi.org/10.1016/j.cger.2016.03.002.PMid:27394021

2. Rahim MA, Mitra P, Zaman S, Habib SH, Afroze SR, Samad T, et al. Frequency, Risk Factors and Antibiotic Sensitivity Pattern of Extended-Spectrum BetaLactamase Producing Escherichia coli and Klebsiella pneumoniae Causing Urinary Tract Infection: Experience from a Tertiary Care Hospital of Bangladesh. BIRDEM Med J 2017;7(2):155-159. https://doi.org/ 10.3329/birdem.v7i2.32455
3. Nitzan O, Elias M, Chazan B, Saliba W. Urinary tract infections in patients with type 2 diabetes mellitus: review of prevalence, diagnosis, and management. Diabetes Metab Syndr Obes 2015;8:129-136.https:// doi.org/ 10.2147 / DMSO.S5 1792.PMid:25759592 PMCid: PMC4346284

4. Artero A, Inglada L, Gómez-Belda A, Capdevila JA, Diez LF, Arca A, et al. The clinical impact of bacteremia on outcomes in elderly patients with pyelonephritis or urinary sepsis: A prospective multicenter study. PLoS ONE 2018;13(1):e0191066. https://doi.org/10.1371/ journal.pone.0191066.PMid:29364923 PMCid: PMC 5783370

5. Peach BC, Garvan GJ, Garvan CS, Cimiotti JP. Risk Factors for Urosepsis in Older Adults: A Systematic Review. Gerontol Geriatr Med 2016 Jan-Dec;2: 2333721416638980. https://doi.org/10.1177/2333 721416638980.PMid:28138493 PMCid: PMC5119864

6. Fennell J, Vellinga A, Hanahoe B, Morris D, Boyle F, HigginsF, et al. Increasing prevalence of ESBL production among Irish clinical Enterobacteriaceae from 2004 to 2008: an observational study. BMC Infect Disease 2012;12:116-123. https://doi.org/10.1186/ 1471-2334-12-116.PMid:22587773 PMCid: PMC34 62136

7. Kang C-I, Cha MK, Kim SH, Ko KS, Wi YM, Chung DR, et al. Clinical and Molecular Epidemiology of Community-Onset Bacteremia Caused by ExtendedSpectrum Beta-Lactamase-Producing Escherichia coli over a 6-Year Period. J Korean Med Sci 2013; 28:9981004.https://doi.org/10.3346/jkms.2013.28.7. 998.PMid:23853481 PMCid: PMC3708098

8. Iqbal S, Rahim MA, Samad T, Ananna MA, Mitra P, Chowdhury TA. Extended-Spectrum Beta-Lactamase Producing Escherichia coli and Klebsiella pneumoniae are Emerging as Major Pathogens Responsible for Urinary Tract Infection. Bangladesh Crit Care J September 2015;3(2):49-52.https://doi.org/10.3329/ bccj.v3i2.25109

9. Fernando MMPSC, Luke WANV, Miththinda JKND, Wickramasinghe RDSS, Sebastiampillai BS, Gunathilake MPML, et al. Extended spectrum beta lactamase producing organisms causing urinary tract infections in Sri Lanka and their antibiotic susceptibility pattern -A hospital based cross sectional study. BMC Infectious Diseases 2017;17:138. https://doi.org/ 10.1186/s12879-017-2250-y.PMid:28187754 PMCid: PMC5303299

10. Clinical and Laboratory Standards Institute. 2012. Performance standards for antimicrobial susceptibility testing. Twenty second informational supplement update. CLSI document M100-S22 U. Clinical and Laboratory Standards Institute, Wayne, PA. 
11. Shawa E, Benitob N, Rodríguez-Bañoc J, Padillad B, Pintadoe V, Calbof E, et al. Risk factors for severe sepsis in community-onset bacteraemic urinary tract infection: Impact of antimicrobial resistance in a large hospitalised cohort. J Infect March 2015;70(3):247-254. https:// doi.org/10.1016/j.jinf.2014.09.011. PMid:25305497

12. Hsiao CY, Yang HY, Chang CH, Lin HL, Wu CY, Hsiao MC, et al. Risk Factors for Development of Septic Shock in Patients with Urinary Tract Infection. Biomed Res Int 2015;2015:717094.https:/ /doi.org/10.1155/2015/ 717094.PMid:26380292 PMCid:PMC4561874

13. Mohseny AB, van Velze V, Steggerda SJ, Smits-Wintjens VEJH, Bekker V, Lopriore E. Late-onset sepsis due to urinary tract infection in very preterm neonates is not uncommon. Eur J Pediatr 2018;177:33-38.https:// doi.org/10.1007/s00431-017-3030-9.PMid:29063210 PMCid:PMC5748400

14. Pien BC, Sundaram P, Raoof N, Costa SF, Mirrett S, Woods CW. The clinical and prognostic importance of positive blood cultures in adults. Am J Med 2010; 123:819-828. https://doi.org/10.1016/j.amjmed. 2010.03.021.PMid:20800151

15. Ben-Ami R, Rodríguez-Baño J, Arslan H, Pitout JDD, QuentinC, Calbo ES, et al. A Multinational Survey of Risk Factors for Infection with Extended-Spectrum âLactamase-Producing Enterobacteriaceae in Nonhospitalized Patients. Clin Infect Dis 2009; 49(5):682-690. https://doi.org/10.1086/6047 13.PMid: 19622043

16. Shaikh S, Fatima J, Shakil S, Rizvi SMD, Kamal MA. Riskfactors for acquisition of extended spectrum bata lactamase producing Escherichia coli and Klebsiella pneumoniae in North-Indian hospitals. Saudi J Biol Sci 2015;22:37-41. https://doi.org/10.1016/j.sjbs. 2014.05.006.PMid:25561881 PMCid: PMC428 1604

17. Rubio-Perez I, Martin-Perez E, Garcia DD, Calvo MLB, Barrera EL. Extended-spectrum beta-lactamaseproducing bacteria in a tertiary care hospital in Madrid: epidemiology,risk factors and antimicrobial susceptibility patterns. Emerg Health Threats J 2012;5:11589. https://doi.org/10.3402/ehtj.v5iO. 11589.PMid:22822411 PMCid:PMC3400742

18. Chander A, Shrestha D. Prevalence of extended spectrum betalactamase producing Escherichia coli and Klebsiella pneumoniae urinary isolates in a tertiary care hospital in Kathmandu, Nepal. BMC Res Notes 2013;6:487.https://doi.org/10.1186/1756-0500-6487. PMid:24274894 PMCid:PMC4222089

19. Artero A, Esparcia A, Eiros JM, Madrazo M, Alberola J, Nogueira JM. Effect of Bacteremia in Elderly Patients with Urinary Tract Infection. Am J Med Sci. 2016; 352:267-271. https://doi.org/10.1016/j.amjms.2016. 05.031.PMid:27650231

20. Hsu CY, Fang HC, Chou KJ, Chen CL, Lee PT, Chung HM. The clinical impact of bacteremia in complicated acute pyelonephritis. Am J Med Sci 2006; 332:175180. https://doi.org/10.1097/00000441-20061000000004. PMid:17031242

21. Chen Y, Nitzano, Saliba W, Chazan B, Coldner R, Raz B. Are blood cultures necessary in the Management of women with complicated pyelonephritis? J Infect 2006; 53:235-240. https://doi.org/10.1016/j.jinf.2005. 12.005. PMid: 16434102

22. Lim CH, Hwang JS, Kim DJ, Jang SH, Son JH, Cho DS, et al. Risk Factors of Sepsis in Obstructive Acute Pyelonephritis Associated with Urinary Tract Calculi. Urogenit Tract Infect 2015;10(2):108-111.https:// doi.org/10.14777/uti.2015.10.2.108

23. Orenstein R, Bross JE, Dahlmann M. Risk factors for urinary lithotripsy-associated sepsis. Infect Control Hosp Epidemiol 1993 Aug;14(8):469-472.https:// doi.org/10.1086/646781 PMid:8376737

24. D’Addessi A, Vittori M, Racioppi M, Pinto F, Sacco E, Bassi PF. Complications of Extracorporeal Shock Wave Lithotripsy for Urinary Stones: To Know and to Manage Them-A Review. The Scientific World Journal 2012; Article ID 619820. https://doi.org/10.1100/2012/ 619820.PMid:22489195 PMCid:PMC3317539 